\title{
Implementation of Physical Education Program of Selected State Universities in CALABARZON Region, Philippines in relation to Students Skills Development Liza L. Bartolome, Ph. D.
}

Faculty, Laguna State Polytechnic University SantaCruz, Laguna, Philippines

\begin{abstract}
This study aims to assess the implementation of physical education of selected state universities in CALABARZON area. The study conducted in five state universities in CALABARZON. Each state university has 250 students, 1 head and 5 PE teachers.

The researcher it seeks to answer the following problems. What is the extent of implementation of this physical education in state universities in CALABARZON in terms of: Physical resources? Human resources? Instructional Materials? Strategies? and Evaluation? What are the skills developed by the students as reflected in the performance evaluation in terms of: Conceptual? Psychomotor? And Affective? Is there a significant relationship between the implementation of the physical education in state universities and the skills developed by the students? What problems are encountered by the respondents in the implementation of the physical education program in state universities? What action plan can be developed to enhance the implementation of the physical education program in state universities in CALABARZON?

The hypothesis that will be tested for acceptance or rejection using 0.05 level of significance are: There is no significant relationship between the implementation of the physical education in state universities and the skills developed by the students.

It is focused on the management of physical education delivery mechanisms of the selected main campus of the said universities and fragmented into four (4) areas of investigation, namely the status of physical education delivery mechanism, the level of management skills deployed by the said universities, the components of the physical fitness as enhanced by the said mechanism and the assessment of the implementation of the physical education delivery among their students in CALABARZON on local and global spheres.

It is limited further to the use of descriptive method research in gathering and treating the data for the above areas of investigating utilizing the systemic sampling technique in the actual selection of the respondents for the said study.
\end{abstract}

Keywords: Implementation, Physical Education, Skills Development

\section{Background of the Study}

Physical education has undergone many vicissitudes and several changes of direction. Time was when physical education was considered as education of the physical, hence, a well built physique was considered as a physically educated body. The activities then were such terms as "drill", "physical training " and calisthenics. This old concept of physical education would in all respects mean today as strengthening the muscles.

The newer and modern concept of physical education is education through physical activities. In modern physical education parlance it is education through "movement." Wunderlich (2009) says of movement: It provides sensory data. It broadens the perceptive horizon. It stimulates function and structure of all bodily organs. It is the means by which an individual learns about himself in relation to his ambient environment. What in addition education through movement more particularly entails is the taking of that culture based family of activities and processes- games, dance, gymnastics, athletic sports, and outdoor pursuits - as a 
means "through" which the teacher can help effect desirable outcomes, regardless of whether or not those activities have intrinsic worth of their own.

By definition, Physical Education is an integral part of the educational program designed to promote the optimum development of the individual physically, socially, emotionally, and mentally through total body movement in the performance of properly selected physical activities.

The three functions of Physical Education are (1) Biologic function which refers to the enhancement of the individual's growth and development through body movement. (2). Integrative function which refers to personality integration achieved through participation in properly selected physical education activities. (3) Social function which is that of transmitting values and standards that is consistent with the needs and ideals of society.

The objectives of Physical Education are (1) Physical development where through the carefully selected physical education activities an individual who participates actively will develop and maintain good health and a high level of physical fitness. (2) Social development where participation in the physical activities provides opportunities for the development of desirable social traits: Friendliness, Cooperation, Respect for the rights of others, Good sportsmanship, Good leadership and follower ship, and Honesty in group competition. (3) Emotional development which offers for self-expression and emotional mastery. Worthwhile emotional traits are self-confidence, self-control, self-reliance, courage and determination. (4) Mental development where through participation in physical education facilities activities the individual develops his mental capacities as he learns the mechanical principles underlying movements, as he acquires knowledge and understanding of rules and strategies of games and sports, and as he discovers ways of improving his movements in gymnastics and dance

It is generally observed that physical education is often regarded as much less important as other learning areas. This attitude of teachers towards the subject leads to the non-attainment of the national development goals in general and preservation of man and his environment in particular.

Educators should have enhanced the quality of physical, social, emotional and intellectual well-being of a person, the students in particular and citizenry in general.

As conceived by the researchers, the way is opened for physical education delivery mechanisms in CALABARZON comprising of the five provinces in acronymatic order, namely: Cavite, Laguna, Batangas, Rizal and Quezon.

CALABARZON is one of the regions of the Philippines. It is designed as Region IV-A and its regional center is Calamba City in Laguna. The region is also more formally known as Southern Tagalog Mainland.

The region is in southwestern Luzon, just south and east of Metro Manila and is the second most densely populated region. CALABARZON and MIMAROPA were previously combined together as Southern Tagalog, until they were separated in 2002 by virtue of Executive Order No. 103. Executive Order No. 246, dated October 28, 2003, designated Calamba City as the regional center of CALABARZON. The largest city of CALABARZON Region and the second highly-urbanized city is Antipolo City, with Lucena City being the first. CALABARZON is the most populated region in the Philippines, with a population of 12,609,803 inhabitants.

CALABARZON has a population of 12.61 million people, the largest of all the regions in the Philippines, with $49.9 \%$ being male and $50.1 \%$ being female. The population growth rate between 2000 and 2010 of $3.07 \%$ decreased from the growth rate between 1990 and 2000 of $3.91 \%$, a trend which coincided with rest of the nation. Life expectancy for men in CALABARZON is 68.9 years and 75.2 years for women.

Apparently however, the out-of-school youth whose number increases every year as more students drop out of school due to poverty are beset by unemployment and lack of employment and lack of employable skills. Added to this is the problem of malnutrition. Many of them fall prey to petty crimes, and the persons present an abject picture of society's neglect of its young as reported by Philippine Regional Profiles (2009) the incidence of malnutrition in the region is grim, dominant most probably among pre-schoolers or 2.9 million children. The health services and nutrition problem should be given more attention in this region. 
Toward this end, state universities have exerted their efforts by making physical education management delivery mechanisms accessible and thus producing healthy fit citizens who are physically fit in relating to their cardiovascular health, strength and endurance, psychological well-being, self image and social interaction with their surroundings in the region on the local and global spheres.

As spelled out in article XIV, section 19 subsections 1 and 2 of the 1987 Philippine Constitution, "The State shall promote physical education and encourage sports programs, league competitions, and amateur sports, including training for international competitions, to foster self-discipline, teamwork, and excellence for the development of a healthy and alert citizenry" and "all education institutions shall undertake regular sports activities throughout the country in cooperation with athletic clubs and other sectors" respectively.

Anchored on the above constitutional mandate, state universities in CALABARZON are required to undertake regular sports activities in cooperation with athletic clubs and other sectors geared toward the discovery of the natural born superior athletes who may be trained for international competitions, particularly the Olympics. In this case therefore, promoting sports and physical fitness have been an internal part of the educational program of the state universities in the region in their efforts toward nation-building.

Records in the different schools will show that some of the students have non-communicable ailments and are non-participative in the school activities. Toward this end, with the effective implementation of the physical education management delivery can ultimately reduce health hazard in terms of non-communicable diseases, health risk and physical inactivity of the people, thereby promoting good health in CALABARZON

However, blunders to all these efforts by the state universities can be uprooted by digging deeper into their actual delivery in managing their physical education programs for the youth in CALABARZON and thus, the rationale behind why this study was so imperative.

For this reason, if the co relational level between and among the independent, intervening and dependent variables is very low, which means the delivery mechanisms of the physical education programs in the selected state universities in CALABARZON are defective and inefficient, these are transmitted back to the input for evaluation and analysis in the form of feedbacks wherein adjustments and modifications will be made by overhauling and streamlining the physical education delivery mechanisms and thus making them effective and efficient in fostering self-discipline, teamwork and excellence for the development of a healthy and alert citizenry in Region IV-A.

\section{Objectives}

This study aims to assess the implementation of physical education of selected state universities in CALABARZON area.

Specifically, it will seek answers to the following problems:

1. What is the extent of implementation of the physical education in state universities in CALABARZON in terms of:
1.1. Physical resources
1.2. Human resources
1.3 Instructional Materials
1.4 Strategies
1.5 Evaluation

of:

2. What are the skills developed by the students as reflected in the performance evaluation in terms
2.1 Conceptual
2.2 Psychomotor
2.3 Affective

3. Is there a significant relationship between the implementation of the physical education in state universities and the skills developed by the students?

4. What problems are encountered by the respondents in the implementation of the physical 
education program in state universities?

5. What action plan can be developed to enhance the implementation of the physical education program in state universities in CALABARZON?

\section{Related Literature}

"Physical education is the study, practice, and appreciation of the art and science of human movement" (Harrison, Blakemore, and Buck, 2009). While movement is both innate and essential to an individual's growth and development, it is the role of physical education to provide instructional activities that not only promote skill development and proficiency, but also enhance an individual's overall health. Physical education not only fulfills a unique role in education, but is also an integral part of the schooling process.

Physical education trends have developed recently to incorporate a greater variety of activities besides typical sports. Introducing students to activities like bowling, walking/hiking, or Frisbee at an early age can help students develop good activity habits that will carry over into adulthood. Some teachers have even begun to incorporate stress-reduction techniques such as yoga, deep-breathing and tai chi. Tai chi, an ancient martial arts form focused on slow meditative movements is a relaxation activity with many benefits for students.

Studies have shown that tai chi enhances muscular strength and endurance, cardiovascular endurance, and provides many other physical benefits. It also provides psychological benefits such as improving general mental health, concentration, awareness and positive mood. It can be taught to any age student with little or no equipment making it ideal for mixed ability and age classes. Tai chi can easily be incorporated into a holistic learning body and mind unit. Teaching non-traditional sports to students may also provide the necessary motivation for students to increase their activity, and can help students learn about different cultures. For example, while teaching a unit about lacrosse (in, say, Arizona, USA), students can also learn a little bit about the Native American cultures of the Northeast and Eastern Canada, where lacrosse originated. Teaching non-traditional (or non-native) sports provides a great opportunity to integrate academic concepts from other subjects as well (social studies from the example above), which may now be required of many P.E. teachers. The four aspects of P.E. are physical, mental, social, and emotional.

Another trend is the incorporation of health and nutrition to the physical education curriculum. The Child Nutrition and WIC Reauthorization Act of 2004 required that all school districts with a federally funded school meal program develop wellness policies that address nutrition and physical activity. ${ }^{\text {WWhile teaching }}$ students sports and movement skills, P.E. teachers are now incorporating short health and nutrition lessons into the curriculum. This is more prevalent at the elementary school level, where students do not have a specific Health class. Recently most elementary schools have specific health classes for students as well as physical education class. With the recent outbreaks of diseases such as swine flu, school districts are making it mandatory for students to learn about practicing good hygiene along with other health topics. Today many states require Physical Education teachers to be certified to teach Health courses. Many colleges and Universities offer both Physical Education and Health as one certification. This push towards health education is beginning in the intermediate level, including lessons on bullying, self-esteem and stress and anger management.

\section{Importance of the Physical Education}

Physical education plays a vital role in the students' development and growth. According to recent medical studies, physical well being of a student is directly related to his or her performance whether in class or in the office. The article will give you reasons to agree.

1. it's a link to good health. The value of physical fitness can never be overstated. It's only in physical educational classrooms that students learn the value of taking care of themselves thru proper grooming, healthy eating and regular exercise.

2. It's a preventive measure against disease. Many doctors today agree that obesity is a serious health risk. Without any form of diet management and control with the numerous processed food students 
intake everyday compounded by a sedentary lifestyle, a student's health can easily be at risk to many diseases like chronic heart disease, hypertension and diabetes. Physical education in school is a preventive measure to teach students the value of regular exercise.

3. It's a program for muscle strength and fitness. Physical education develops the students' motor skills and hand-eye coordination. It also develops the upper body muscles through activities like doing push ups as well the lower body muscles through stationary jumping jacks, 3 min running and jumping exercises. Programs usually have core training exercises also like doing abdominal crunches.

4. It promotes academic learning. Physical health allows students to function even better in classrooms. A good cardiovascular system developed from regular exercise promotes excellent blood and oxygen circulation. This means more nutrients circulate through out the body which includes the brain. This circulation produces longer attention span during classes allowing longer concentration and absorption.

5. It builds self esteem. Students who are active in physical activities like basketball, volleyball, martial arts and running just to name a few are more confident with themselves according to most social school studies. It's probably because of the self discipline and dedication to excel in a sport that brings out the best in students. In school, the physical education program introduces these sport activities to students allowing them to make choices to which sport areas they want to get involved in.

6. It develops cooperation, teamwork and sportsmanship skill. Most physical education programs are holistic. The program allows student to interact together to a common goal and that is to win and excel physically. It brings out the competitive sides of students working both body and mind but also promotes sportsmanship.

7. It promotes a physically active lifestyle. The purpose of physical education is to instill in students, at an early age, the value of self preservation and choosing a lifestyle that is good for both the mind and body.

\section{Correlation between brain development and physical education}

Research has shown that there is a positive correlation between brain development and exercising. Incorporating local indigenous knowledge into physical education can lead to many meaningful experiences and a way of learning about other cultures. For example by incorporating traditional knowledge from varying indigenous groups from across Canada students can be exposed to a many concepts such as holistic learning and the medicine wheel. A unit could be focused on connecting to a place or feeling while outdoors, participating in traditional games, or outdoor environmental education. These types of lesson can easily be integrated into other parts of the curriculum and give Aboriginal students a chance to incorporate their culture in the local school community

Studies have been done in how physical education can help improve academic achievement. In a 2007 article, researchers found a profound gain in student's English Arts standardized testing students who had 56 hours of physical education in a year compared to like students who had 28 hours of physical education a year.

In Brazil, the physical education curriculum is designed to allow school pupils a full range of modern opportunities, dozens of sports and hundreds of carefully reviewed drills and exercises, including exposure to education with the use of pedometer, GPS, and heart rate monitors, as well as state-of-the-art exercise machines in the upper grades. Some martial arts classes, like wrestling in the United States, and Pencak Silat in France, Indonesia, and Malaysia, are taught to teach children self-defense and to feel good about themselves. The physical education curriculum is designed to allow students to experience at least a minimum exposure to the following categories of activities: aquatics, conditioning activities, gymnastics, individual/dual sports, team sports, rhythms, and dance. Students are encouraged to continue to explore those activities in which they have a primary interest by effectively managing their community resources.

In these areas, a planned sequence of learning experiences is designed to support a progression of student development. This allows kids through 6th grade to be introduced to sports, fitness, and teamwork in order to 
be better prepared for the middle and high school age. In 1975, the United States House of Representatives voted to require school physical education classes include both genders. ${ }^{[7]}$ Some high school and some middle school PE classes are single-sex. Requiring individuals to participate in physical education activities, such as dodge ball, flag football, and other competitive sports remains a controversial subject because of the social impact these have cases physical education programs have been cut.

\section{Technology use in physical education}

New technology in Physical education is playing a big role in classes. One of the most affordable and effective is a simple video recorder. With the use of a video recorder students can see the mistakes they're making in things such as a throwing motion or swinging form. ${ }^{[8]}$ Studies show that students find this more effective than having someone try to explain what they are doing wrong, and then trying to correct it. Educators also found the use of other technologies such as pedometers and heart rate monitors very successful, using them to make step and heart rate goals for students.

Other technologies that can be used in a Physical Education setting would include video projectors, GPS and even gaming systems such as Kinect, Wii Fit and Dance Dance Revolution. Projectors can be used to show students things such as proper form or how to play certain games. GPS systems can be used to get students active in an outdoor setting and active exergames can be used by teachers to show students a good way to stay fit in and out of the classroom setting ${ }^{[11]}$

Another type of technology that is commonly used in Physical Education is the use of pedometers. Pedemeters do not necessarily track how far a person is going, but it lets them know the number of steps they are making. It will let them know how many steps on average they are making and want to strive to get more the next class. There are many lessons that you can use for many grade levels when you are teaching students to use a pedometer it is important to make it a game, especially for younger students.

\section{Curriculum}

According to the American Alliance for Health, Physical Education, Recreation and Dance (AAHPERD), a quality physical education program for grades $\mathrm{K}-12$ includes instructional periods totaling at least 150 minutes per week at the elementary level and 225 minutes at the secondary level, qualified physical education specialists, and adequate equipment and facilities. In general, the curriculum should consist of: (a) instruction in a variety of developmentally appropriate motor skills that challenge students to develop physically, cognitively, socially, and emotionally; (b) fitness activities that educate and help students understand and improve or maintain optimal fitness levels; (c) instruction in concepts that lead to a better understanding of motor skills and fitness development; (d) opportunities to engage in experiences that enhance cooperation and develop multicultural awareness; and (e) experiences that foster the desire for lifelong participation in physical activity.

More specifically, the elementary curriculum should include many enjoyable activities that lead to the acquisition and refinement of fundamental motor patterns (e.g., running, skipping, jumping, catching, throwing, striking, balancing) that can be applied in game, sport, dance, and gymnastics contexts. The movement-based curriculum proposed and adapted by George Graham, Shirley Ann Holt/Hale, and Melissa Parker in 1998 introduces skill themes (fundamental motor patterns) and movement concepts that describe how a movement is performed (e.g., speed, direction, relationship). This curriculum pattern teaches children to move while challenging them to explore, modify, and refine motor patterns, and it can be used as a vehicle for teaching physical education. The activity based approach is the most common curriculum pattern used in both middle schools and high schools. This curricular pattern uses activity units in sport, fitness, and dance (e.g., volleyball, aerobic dance, swimming) to teach physical education.

Middle school curriculums should include a wide variety of team and individual sports utilizing motor skills introduced and refined at the elementary level. High school curriculums should focus on lifetime sports skills (e.g., golf, tennis, aerobic dance), with a secondary emphasis on team sports. During the high school 
years, students should become highly proficient in one (or more) sport and/or fitness activity of their own choosing. However, regardless of the level of schooling, fitness forms the base of the curriculum and it is an integral part of the program.

\section{Trends, Issues, and Controversies}

School accountability, a major trend of the 1990s, has driven the need for national assessment (testing) and standards. This trend has become an issue and has created debate throughout education, including physical education. Proponents on both sides have valid points to make. Those who oppose national testing point out the need for people to enjoy physical activity. They believe that testing does not foster the desire for lifelong participation. In contrast, proponents of testing think it would parallel work completed in other disciplines, such as math and science, while helping students gauge their progress towards a national standard for fitness and/or skill competence.

The National Association for Sport and Physical Education has provided guidelines in the form of gradelevel benchmarks, as well as an operational definition of the physically educated person. Such a person is skillful in a variety of physical activities, physically fit, participates regularly in physical activity, knows the benefits of physical activity, values physical activity and its contributions to a healthy lifestyle, respects diversity, and acts in a socially responsible manner. The question remains, however, of how much direction and specificity in the form of standards and assessment are needed.

In many school programs and business settings, the term wellness has replaced fitness and health. In general, this term refers to optimal health and well-being, but it has been broadened to include the dimensions of emotional, mental, spiritual, social, and environmental well-being.

There are many issues that are of interest to all educators, issues that pose a challenge to all of those who seek to teach children. These include discipline problems, student drug abuse, violence, insufficient resources, lack of parental support for education, large classes, teacher burnout, and perhaps most importantly, a concern for the health and well-being of all children.

By far the greatest issue facing physical education in $\mathrm{K}-12$ institutions is the reduction of time in the curriculum allotted to this important subject. The need for daily physical education is obviously important for the well-being of students, but it presents a dilemma for those who must balance academics, accountability, and what is best for the child's overall education. Given the support for the physical and psychological contributions of exercise, along with the health risks associated with inactivity, it is clear that daily physical education plays a crucial and unique role in each child's cognitive, psychological, and physical development.

\section{Instructional Materials}

As claimed by Arey (2008) physical resources for health educational service delivery must be included in the material budget and purchasing program in order to sustain the consistency of the said deliverance.

The same claim has been divulged by Bell (2009) that physical resources must jibe with the kind of service delivered in order not to suffer from economic wastage. In this case, materials and supplies must first be identified before resulting into budgetary allotment for purchases of physical resources intended primarily for health service delivery.

The opinion of Chaffee (2010) sustained the above viewpoints by stipulating that physical resources must be subject for budgetary control in order to eliminate corruptions and thus eliminate wastages for monetary support of whatever health service delivery is made.

The foregoing viewpoints have bearing on the present research undertaking along physical resources of the selected state universities for physical education delivery mechanisms in CALABARZON.

\section{Human Resources}


Chapman (2008) stressed out that human resources allocated are vital for effective health service delivery as their educational qualifications and empirical experiences are plus factors in the enhancement of whatever programs and projects so designed for humanitarian purposes.

On the similar vien, Haupt (2010) realigned his concept of human resources as elemental in the success of health service deliverance to the population. More likely, the determination of human resource requirement is gauged in terms quality of workers deployed in the program.

More likely, Huxley (2010) has this to say that human resources are measured in terms of the quality people deployed for health service delivery. This simply means that the more qualified and experienced are the human resources, the better are the health services rendered.

The above literary citations helped the researcher see in her own study the historical and associational similarity when speaking of the human resources discharged by the selected state universities to carry on the delivery mechanisms of their physical education programs intended for the youths in CALABARZON.

\section{Technical Skills}

According to Arul (2012) technical skill implies an understanding of and proficiency in a specific kind of activity, particularly one involving methods, processes, procedures, or techniques, it involves specialized knowledge, analytical ability within that specialty, and facility in the use of the tools and techniques of the specific discipline.

A parallel implication has been conceived by Amoore (2008) that technical skill is more of comprehension coupled with analytical and evaluative inferences in drawing conclusions before recommendations are thoroughly endorsed.

By and large, Katz (2008) amplified his understanding of technical skill as something more of a methodology and strategy in manipulating devices geared toward the shaping of internal and external disciplines in the individual.

The above literatures have direct similarity and bearing to the present study along the level of management skills deployed by the selected state universities in the delivery of their physical education programs as to technical skill in reaching out the youths in CALABARZON.

\section{Human Skills}

Technical skill was elaborated by Arul in 2012 that there is a human skill for someone to work with, understand and motivate other people in order to lead them for a worthy purpose.

The same connotation was so advanced by Amoore (2009) that a person with a human skill is aware of his own attitudes, assumptions and beliefs about other individuals and groups and thus he is able to see the usefulness and limitations of these feelings.

The higher is the status of the physical education delivery mechanisms in terms of physical and human resources, the more effective are the technical, human and conceptual management skills among students in the state universities in CALABARZON.

The above viewpoints are linked with the advocacy of Langen (2008) when he dispatched the idea that human skill demands sensitivity to the needs and motivations of others geared toward the development and enhancement of their productive activities so they will not suffer from life miseries in the future.

At this point, the above concepts are germane to the basic problem investigated by the present researcher along the level of human management skill as deployed by the selected state universities in the delivery of their physical education programs in Region IV-A, the case of CALABARZON so to speak.

\section{Conceptual Skills}


Conceptual skill involves the ability to see the enterprise as a whole for the simple reason that it includes among others the various functions of the organization as basically dependent on one another, and ultimately how changes in any one part affect all the others, geared toward community development in particular, and the country in general as claimed by Arul (2012).

Katz (2008) amplified further that conceptual skill is nothing more but an involvement of thinking in terms of relative emphasis and priorities; among conflicting objectives and criteria; relative tendencies and probabilities; rough correlations and patterns among elements rather than clear cut cause-and-effect relationship.

For that reason Amoore (2009) laid out his own version of conceptual skill as another way to develop individuals through trading jobs, by moving promising young men and women at the same level of responsibility.

The foregoing bibliographic citations registered a deeper insight for the present researcher to conceptualize a frame of reference for the selected state universities in CALABARZON to deploy effectively the delivery of their physical education programs among their youths and thus preparing them to face squarely the natural and manmade calamities that may come their way without warming.

\section{Psychomotor Skills}

Myers (2009) disclosed that muscular strength increases agility, speed and flexibility. However the essence of maintaining physical fitness may not be achieved without adequate sleep, good nutrition and systemic exercise and the aftermath of which is development of muscular strength.

Nydegger (2008) conceived the essential element of muscular strength as the basic foundation of physical fitness in which case is inseparable from muscular endurance. Apparently, muscular strength varies considerably at different age levels and to a lesser extent among persons of different physiques.

A similar disclosure was propounded by Murray (2009) that muscular strength by all means improves the functioning of the lungs, heart, and blood vessels and helps get rid of mental and physical tensions.

The above foreviews are linked with the components of the physical fitness along the enhancement of muscular strength as fully developed by the physical education delivery mechanisms of the selected state universities in the region.

Myers (2009) was one in pointing out that muscular strength and muscular endurance are inseparable as they go side by side with one another. It is for this reason that physical fitness is sustained by both muscular strength and muscular endurance and therefore both contribute to sustain agility, speed and flexibility of the human body.

More than ever, Nydagger (2008) confected that muscular endurance is an offshoot of a well developed muscular strength for an individual to stay physically fit at all times.

A collateral connection with the foregoing views was sustained by Murray (2009) that muscular endurance is catapulted by muscular strength in the sustenance of physical fitness of the individual.

It is within the above context that the basic question raised in the present investigation is germane with one another particularly along muscular endurance as enhanced by the physical education delivery mechanisms of selected state universities in CALABARZON.

Rebuck (2008) characterized that physical fitness is sustained also by circulatory-respiratory endurance other than muscular strength and muscular endurance. In this case the circulatory system nourishes every part of the body. The fluid bathing the body tissues is blood; the pump circulating the blood is the heart, the tubes through which the blood flows are the blood vessels and thus respiratory endurance is ultimately attained.

As implicitly conceived by Reich (2008), circulatory-respiratory endurance is basically sustained by a well-balanced diet vital for the building of body tissues and thus provide energy to keep the individual physically fit. 
It is therefore apparent as claimed by Schwartz (2008) that circulatory-respiratory endurance can be attained side by side with muscular strength and endurance for the simple reason that circulatory is nourisher of the body whereas the respiratory is the linker of the body and its environment. By and large, as the circulatory pumps the blood to all parts of the body, the respiratory exchanges the gases between the blood and the air taken into the lungs wherein intake of oxygen and release of carbon dioxide re regularly taking place.

Anchored on the foregoing bibliographic citations, the same suggested avenues of approaches for the present researcher to solve her problem areas investigated.

\section{Physical Resources}

Amundsen (2008) conducted a study on the physical resources of country schools for senior citizens of California. Descriptive method of research was used in gathering and treating the data for the problem areas investigated utilizing systematic sampling technique in the selection of the actual sample as the target respondents for the study. His findings revealed that the physical resources were related to the physical fitness of senior citizens of California. He recommended the increase number of physical resources in proportional ratio to the number of incoming participants of the said physical fitness program for this particular group.

Burke (2009) sustained further the findings of the foregoing study when he launched a feasibility study on physical resources for human development program in Chicago. He utilized a forecasting technique in laying out a variable program for human development in the city. His findings revealed of the increase in physical resources after five years in order to cater the needs of the citizens for their human development program affecting their health and nutritional needs.

A collateral field work was conducted by Kahana (2009) incidental to her position paper presented before the participants of seminar and workshop on physical resources for physical fitness program for patients in the rehabilitation center in Boston. She stressed her field work the dire need for physical resources needed to fully rehabilitate the patients for their quick recovery so they can go back to their respective communities as active citizens once again.

The findings of the foregoing studies suggested a technique of dealing with a problematic situation germane to the solution of similar research undertaking relative to the physical resources as delivery mechanisms of the physical education program by the selected state universities in CALABARZON in the said region.

Amundsen (2008) other than physical resources divulged in his institutional research, human resources in terms of qualified medical and dental doctors effectively delivered health services to senior citizens in California.

\section{Human Resources}

A similar revelation was made by Burke (2009) that human resources in his feasibility study made realignment on equal footing with physical resources for effective health service delivery geared toward enhancement of human development program in Chicago five years hence.

Kahana (2009) in her position paper dispatched the much needed human resources for effective physical fitness program for patients quick recovery at rehabilitation center in boston.

The above investigations provided possibilities for the present researcher to explore solutions to her problem areas investigated along human resources as delivery mechanisms deployed in the physical education programs of the selected state universities in CALABARZON.

In the research made by Marmor (2009) on the technical skill development for physical education programs in New Jersey, this must delve deeper into the correct procedures or techniques as basis for overhauling and streamlining the strengths and weaknesses of the said program within the level of ability and facility in the use of physical resources for the said purpose.

A similar finding was revealed by McClelland (2008) that technical skill must be developed 
comprehensively through the use of the tools designed for effective physical education program in Florida.

The findings of the foregoing researchers were strengthened further by McDaniels (2008) when he revealed that technical skill is always focused on a specific kind of activity within the ambit of specialization of the mentors of the physical education program in Pittsburgh.

With the findings revealed by the foregoing researchers, these helped the present researcher to attack the problem areas investigated along the level of technical skill deployed by the selected state universities in the delivery of their physical education programs in the said region.

McClelland (2008) realigned the human management skill with technical aspect to effectively deliver the physical education program through proper motivation of people included in the said program.

A similar gesture was made by Marmor (2009) in realigning the human skill on equal footing with technical skill development for effective delivery mechanism of physical education program in New Jersey by simply considering the attitudes and beliefs of the participants in the said program.

Considerably, McDaniels (2008) recommended that mentors of the physical educations must always be sensitive to the needs and motivation of the participant's so as to lead them toward productive activities in the future.

Thus, the findings of the above studies suggested avenues of approaches in dealing with a problematic situation incidental to the level of human management skill deployed by the selected state universities in the effective delivery of their physical education programs in CALABARZON.

In the study conducted by Marmor (2009) the development of technical and human skills is an exercise of fertility if people in the physical education program lack the ability to see the micro and the macro aspects of the various functionalities on how the mechanisms are delivered to the clienteles.

The same connotation was amplified by McClelland (2008) that technical and human skills are just nothing more but tiny bubbles without conceptual skill in establishing priorities, objectives and criteria so as to achieve effectiveness in the delivery mechanisms of physical education program.

Far and wide McDaniels (2008) similarly recommended that conceptual skill must play side by side with technical and human skills in the development of delivery mechanisms of the physical education programs to the participants.

The above investigators provided leeway for the present researcher solutions to the problem areas investigated with respect to the conceptual management skills in the development of physical education delivery mechanisms to the college students of the said universities in Region IV-A

Juacalla (2013) conducted a study on the management of physical education management as stress reduction of selected state universities in CALABARZON. He utilized descriptive method of research in gathering and treating the data for the problem areas investigated utilizing systematic sampling technique in the selection of the actual respondents of the study. Among others, he revealed an effective physical education system delivery with respect to physical and human resources considering the fiscal management in terms of budget preparation, authorization, executors and accountability so as to effectively deliver the components of the physical fitness programs of the selected universities in CALABARZON.

Apparently, the above study has direct dealing with the present research undertaking along the delivery mechanisms of physical education program by the selected universities in CALABARZON. Though they are not identical in the time frame, both are similar and collateral in the areas investigated.

\section{METHODOLOGY}

This chapter gives careful consideration on research design, population and sampling techniques, research instruments, data gathering procedure and statistical treatment of data in order to provide objectivity and critical insight for the problem areas investigated.

The researcher will utilize the descriptive survey method in gathering and treating the data for the above areas investigated.

As disclosed by Leedy (2008), descriptive method deals with a situation that demands the technique 
of observation; the population for the study must be carefully chosen, clearly defined, and specifically delimited in order to set precise parameters for ensuring the discreteness of the population; data in this kind of method are particularly susceptible to distortion through introduction of bias into the research design and therefore particular attention should be given to safeguard the data from the influence of bias; and those data must be organized and presented systematically so that valid and accurate conclusions may be drawn from them.

From the procedure recapitulated above, the researcher believes that descriptive survey method is empirically essential for this kind of research undertaking.

As conceived by the researchers, the way is opened for physical education delivery mechanisms in CALABARZON comprising of the five provinces in acronymatic order, namely: Cavite, Laguna, Batangas, Rizal and Quezon.

CALABARZON is one of the regions of the Philippines. It is designed as Region IV-A and its regional center is Calamba City in Laguna. The region is also more formally known as Southern Tagalog Mainland.

The region is in southwestern Luzon, just south and east of Metro Manila and is the second most densely populated region. CALABARZON and MIMAROPA were previously combined together as Southern Tagalog, until they were separated in 2002 by virtue of Executive Order No. 103. Executive Order No. 246, dated October 28, 2003, designated Calamba City as the regional center of CALABARZON. The largest city of CALABARZON Region and the second highly-urbanized city is Antipolo City, with Lucena City being the first. CALABARZON is the most populated region in the Philippines, with a population of 12,609,803 inhabitants.

CALABARZON has a population of 12.61 million people, the largest of all the regions in the Philippines, with $49.9 \%$ being male and $50.1 \%$ being female. The population growth rate between 2000 and 2010 of $3.07 \%$ decreased from the growth rate between 1990 and 2000 of $3.91 \%$, a trend which coincided with rest of the nation. Life expectancy for men in CALABARZON is 68.9 years and 75.2 years for women.

Apparently however, the out-of-school youth whose number increases every year as more students drop out of school due to poverty are beset by unemployment and lack of employment and lack of employable skills. Added to this is the problem of malnutrition. Many of them fall prey to petty crimes, and the persons present an abject picture of society's neglect of its young as reported by Philippine Regional Profiles (2009) the incidence of malnutrition in the region is grim, dominant most probably among pre-schoolers or 2.9 million children. The health services and nutrition problem should be given more attention in this region.

This study will be conducted in five state universities in CALABARZON. Each state university will have 250 students, 1 head and 5 PE teachers. The study will be conducted $2^{\text {nd }}$ semester of school year 20132014.

It is focused on the management of physical education delivery mechanisms of the selected main campuses of the said universities and fragmented into the four (4) areas of investigation, namely: 1) The status of physical education delivery mechanisms; 2) The level of management skills deployed by the said universities in the delivery of their physical education programs; 3) The components of the physical fitness as enhanced by the said mechanisms; and 4) The assessment of the implementation of the physical education delivery among their students in CALABARZON on local and global spheres.

It is limited further to the use of descriptive method research in gathering and treating the data for the above areas of investigation utilizing the systemic sampling technique in the actual selection of the respondents for the said study.

Systemic randomized sampling will be employed in this study as this is the least sophisticated and practical of all sampling procedures. This kind of sampling consists of having a population whose texture is either homogeneous or homogenously conglomerate in characteristic.

From a total population parameter of 9,050 representing school heads, physical education teachers and college students of the said universities in CALABARZON, they will be purposely and systematically 
selected into 1,280 as the actual respondents of this study Academic Year 2013-2014.

\begin{tabular}{|c|c|c|c|c|c|c|}
\hline \multicolumn{7}{|c|}{ Frequency Distribution of the Respondents } \\
\hline Respondents & Cavite & Laguna & Batangas & Rizal & Quezon & TOTAL \\
\hline Head & 1 & 1 & 1 & 1 & 1 & 5 \\
\hline PE Teacher & 5 & 6 & 5 & 7 & 4 & 27 \\
\hline Students & 250 & 250 & 250 & 250 & 250 & 1250 \\
\hline
\end{tabular}

TOTAL

The target population parameter will be assigned an even-scheme of random numbers from where the actual respondents will be selected at the time the systematic distribution and retrieval of three (3) sets of questionnaire will be made.

The rationale behind the selection of the above respondents is to elicit answers to the foregoing problem areas investigated with respect to the status of the implementation of the physical education in state universities; the level of management skills of the state universities, the components of the physical fitness as enhanced by the physical education delivery mechanisms, and the significant differences between and among the said variables.

In order to assure the validity and reliability of the actual sample, Sloven's sampling formula will be used.

$\mathrm{n}=\mathrm{N}$

Sampling formula:

$$
1+\mathrm{Ne}^{2}
$$

Where:

$$
\begin{aligned}
& \mathrm{n}=\text { sample size } \\
& \mathrm{N}=\text { population size } \\
& \mathrm{e}^{2}=\text { error of estimate }
\end{aligned}
$$

\section{ANALYSIS, AND INTERPRETATION OF DATA}

This chapter covers the presentation, analysis and interpretation of the data in the light of the research questions formulated in the study.

Problem 1. Extent of Implementation of Physical Education Program of Selected State Universities in CALABARZON in relation to students skills development universities.

The following tables illustrate the status of the implementation of the physical education in state

1.1. Physical Resources. Table 1 displays the extent of implementation of the physical education in state universities in terms of physical resources.

Table 1. Extent of Implementation of the Physical Education in State Universities as to Physical Resources

\begin{tabular}{|l|l|l|l|l|l|l|}
\hline Physical Resource & \multicolumn{2}{l|}{ Student } & \multicolumn{2}{l|}{ Teacher } & \multicolumn{2}{l|}{ Head } \\
\cline { 2 - 7 } & Mean & VI & Mean & VI & Mean & VI \\
\hline Physical Education Gym & 3.31 & I & 3.58 & FI & 3.86 & FI \\
\hline Lecture Room for Physical Education & 2.31 & MI & 2.71 & I & 3.27 & I \\
\hline Chess sets & 2.23 & MI & 3.29 & I & 3.42 & I \\
\hline Swimming Pool & 1.46 & NI & 2.86 & I & 2.48 & MI \\
\hline Track and Field & 2.61 & I & 2.57 & I & 3.53 & FI \\
\hline
\end{tabular}




\begin{tabular}{|c|c|c|c|c|c|c|}
\hline $\begin{array}{l}\text { Facilities such as balls (basketballs and volleyballs, } \\
\text { equipment and the like for all kinds of sports }\end{array}$ & 3.28 & I & 3.57 & FI & 3.62 & FI \\
\hline Ambulance for injured athletes and P.E. students & 2.60 & I & 3.00 & I & 3.27 & I \\
\hline Supplies and materials for Physical Education & 3.05 & I & 3.71 & FI & 3.59 & FI \\
\hline Megaphone, loud speaker and the like during intramurals & 3.58 & FI & 2.90 & I & 3.71 & FI \\
\hline Over-all Mean Score & 2.82 & I & 3.24 & $\mathbf{I}$ & 3.42 & I \\
\hline
\end{tabular}

Data shows that the students assessed that the physical education program fully implement the use of megaphone, loud speaker and the like during intramurals as seen from the mean score of 3.58 but assessed that the use of swimming pool is not implemented as reflected from the mean score of 1.46. On the other hand, the teachers assessed the physical education program utilizing to full implementation the use of the physical Education Gym as indicated from the mean score of 3.58 but assessed that the use of the lecture room for Physical Education implemented based on the mean score of 2.71. Furthermore, the principals assessed that the used of Physical Education Gym was fully implemented while the use of the swimming pool was not implemented as indicated from the mean score of 3.86. As a whole, the three groups of respondents students, teachers and principals assessed that the physical education program was implemented as seen from the over-all mean score of 2.82, 3.24 and 3.42, as in order.

Data reveals that the use of physical education gym is fully implemented but the use of swimming pools in the state universities is not implemented. In an interview with the principals and teachers, they said that construction of the swimming is very expensive that is why they only rent a pool for their swimming classes.

Santos (2009) stressed that to fully operationalize the physical education program, the schools should be equipped with the physical resources that they need like gymnasium, swimming pool, track and field, etc. Burke (2009) sustained further the findings of the foregoing study when he said that the physical resources of the physical education program for effective physical education program for students to enhance health service delivery geared toward enhancement of the students. A similar finding was revealed by McClelland (2008) that technical skill of the students may be developed comprehensively through the use of the physical resources of the schools for effective physical education program.

1.2. Human Resources. Table 2 depicts the extent of implementation of the physical education in state universities in terms of human resources.

Table 2. Extent of Implementation of the Physical Education in State Universities as to Human Resources

\begin{tabular}{|l|l|l|l|l|l|l|}
\hline Human Resources & \multicolumn{2}{l|}{ Students } & \multicolumn{2}{l|}{ Teacher } & \multicolumn{2}{l|}{ Head } \\
\cline { 2 - 7 } & Mean & VI & Mean & VI & Mean & VI \\
\hline $\begin{array}{l}\text { Teachers have the required specialized training and educational } \\
\text { preparation within their specialty }\end{array}$ & 3.58 & FI & 3.43 & I & 3.75 & FI \\
\hline $\begin{array}{l}\text { Meet the educational qualifications of the teachers and department } \\
\text { heads for the physical education service delivery of the university }\end{array}$ & 3.36 & I & 3.43 & I & 3.52 & FI \\
\hline $\begin{array}{l}\text { Meet the required area of specialization of the teachers and heads } \\
\text { of the physical education department }\end{array}$ & 3.12 & I & 3.44 & I & 3.69 & FI \\
\hline $\begin{array}{l}\text { Requires P.E. heads and teachers to be able bodied and mentally } \\
\text { alert, physically and mentally fit }\end{array}$ & 3.48 & I & 3.42 & I & 3.63 & FI \\
\hline Over-all Mean Score & $\mathbf{3 . 3 9}$ & I & $\mathbf{3 . 4 3}$ & I & $\mathbf{3 . 6 5}$ & FI \\
\hline
\end{tabular}

It can be seen from the table that the students assessed the physical education program to fully implement in requiring the teachers to teach by the required specialized training and educational preparation within their specialty as seen from the mean score 3.58 but assessed that meeting the required area of specialization of the teachers and heads of the physical education department implemented based on the mean 
score 3.44. On the other hand, the teachers assessed that the physical education program implemented in meeting the required area of specialization of the teachers and heads of the physical education department and in requiring P.E. heads and teachers to be able bodied and mentally alert, physically and mentally fit as indicated from the mean score of 3.44 and 3.42, respectively. Furthermore, the principal assessed that teachers have the required specialized training and educational preparation within their specialty and meet the educational qualifications of the teachers and department heads for the physical education service delivery of the university as reflected from the mean score of 3.75 and 3.52, respectively. As a whole, the principal assessed the physical education program fully implemented as seen from the over-all mean score of 3.65 but the students and teachers assessed it implemented as reflected from the over-all mean score of 3.39 and 3.43, respectively.

In an interview with the respondents, they said that they are in the process of continuously upgrading the human resources of the physical education program to meet the standards set by the Department of Education. The teachers and the head/dean are encouraged to pursue graduate programs and attend seminars and conferences. As defined by Santos (2008) human resources refer to the human aspects in terms of principals, teachers, coaches and staff in the physical education program of the said universities in CALABARZON.

Chapman (2008) pointed out that the human resources are vital for effective physical education service delivery as their educational qualifications and empirical experiences are plus factors in the enhancement of whatever programs and projects so designed for the students.

On the similar view, Huxley (2010) has this to say that human resources are measured in terms of the quality people deployed for physical education delivery. This simply means that the more qualified and experienced are the heads/deans, teachers and staff, the better are the services rendered.

1.3 Instructional Materials. Table 3 projects the extent of implementation of the physical education in state universities in terms of instructional materials.

Table 3. Extent of Implementation of the Physical Education in State Universities as to Instructional Materials

\begin{tabular}{|l|l|l|l|l|l|l|}
\hline Instructional Materials & \multicolumn{2}{l|}{ Students } & \multicolumn{2}{l|}{ Teacher } & \multicolumn{2}{l|}{ Head } \\
\cline { 2 - 7 } & Mean & VI & Mean & VI & Mean & VI \\
\hline $\begin{array}{l}\text { Uses books, manuals, teaching guides, modules, etc. in } \\
\text { teaching physical education }\end{array}$ & 3.32 & I & 2.29 & MI & 3.83 & FI \\
\hline $\begin{array}{l}\text { Uses modern tools in teaching like computers, powerpoint } \\
\text { presentation, etc. }\end{array}$ & 3.07 & I & 3.00 & I & 3.24 & I \\
\hline Uses practical learning exercise in teaching physical education & 3.32 & I & 3.14 & I & 3.57 & FI \\
\hline $\begin{array}{l}\text { Teachers have the facility in the use of the tools and techniques in } \\
\text { the delivery of physical education instruction }\end{array}$ & 3.20 & I & 3.71 & FI & 3.42 & I \\
\hline $\begin{array}{l}\text { Develop instructional materials suited to the needs of the students } \\
\text { in learning physical education }\end{array}$ & 3.75 & FI & 3.14 & I & 3.38 & I \\
\hline Utilize appropriate instructional materials & 3.11 & I & 3.14 & I & 3.75 & FI \\
\hline Over-all Mean Score & $\mathbf{3 . 3 0}$ & I & $\mathbf{3 . 0 7}$ & I & $\mathbf{3 . 5 3}$ & FI \\
\hline
\end{tabular}

Data shows that the students assessed the physical education program fully implemented the development of instructional materials suited to the needs of the students in learning physical education as indicated from the mean score 3.75, but implemented the use of modern tools in teaching like computers, powerpoint presentation, etc. as seen from the mean score 3.07.

The teachers, on the other hand, assessed that the schools fully implemented the utilization of their facility in the use of the tools and techniques in the delivery of physical education instruction as reflected 
from the mean score 3.71 but assessed the use of books, manuals, teaching guides, modules, etc. in teaching physical education implemented as seen from the from the mean score of 3.29. Furthermore, the head/dean assessed that the use of books, manuals, teaching guides, modules, etc. in teaching physical education fully implemented as reflected from the mean score of 3.83, but assessed the use of modern tools in teaching like computers, powerpoint presentation, etc. implemented based on the mean score 3.24. As a whole, it was found out that the heads/deans have assessed that the physical education program was fully implemented as seen from the mean score of 3.53 while the students and teachers assessed it implemented as reflected from the mean score of $3.30 \quad$ and 3.07 , respectively.

In an interview with the respondents, they said that they are trying to do their best to maximize the use of instructional materials in teaching physical education.

According to Lemuel (2008) the use of modern tools in teaching like computers, powerpoint presentation, etc. can enhance students' learning. The teachers utilized the use of tools and techniques in the delivery of physical education instruction. As claimed by Arey (2008) instructional materials for physical education program must be included in the material budget and purchasing program in order to sustain the consistency of the delivery of service.

1.4 Strategies. Table 4 describes the extent of implementation of the physical education in state universities in terms of strategies.

Table 4. Status of the Implementation of the Physical Education in State Universities as to Strategies

\begin{tabular}{|c|c|c|c|c|c|c|}
\hline \multirow[t]{2}{*}{ Strategies } & \multicolumn{2}{|c|}{ Students } & \multicolumn{2}{|c|}{ Teacher } & \multicolumn{2}{|l|}{ Head } \\
\hline & Mean & VI & Mean & VI & Mean & VI \\
\hline $\begin{array}{l}\text { Utilize specific kind of activity particularly } \\
\text { involving the methods, processes, procedures and } \\
\text { techniques relative to the physical education } \\
\text { program of the university }\end{array}$ & 3.40 & I & 2.29 & MI & 3.74 & FI \\
\hline Utilize various types of teaching approaches & 3.12 & I & 3.43 & I & 3.68 & FI \\
\hline $\begin{array}{l}\text { Use teaching strategies to carry out specific learning } \\
\text { tasks }\end{array}$ & 3.16 & I & 3.44 & I & 3.55 & FI \\
\hline Apply computer-aided instruction in teaching & 2.70 & I & 3.00 & I & 2.49 & MI \\
\hline $\begin{array}{l}\text { Proficient in a specific kind of activity particularly } \\
\text { involving the methods, processes, procedures and } \\
\text { techniques relative to the physical education } \\
\text { program of the university }\end{array}$ & 3.16 & I & 2.86 & I & 3.57 & FI \\
\hline Over-all Mean Score & 3.14 & I & 3.00 & I & 3.41 & I \\
\hline
\end{tabular}

Findings show that the students assessed the physical education program that it fully implemented utilization of specific kind of activity particularly involving the methods, processes, procedures and techniques relative to the physical education program of the university and in utilization of the various types of teaching approaches as seen from the mean score of 3.40 and 3.12, respectively.

On the other hand, the teachers assessed the use of teaching strategies to carry out specific learning tasks implemented as indicated from the mean score of 3.44 and assessed the utilization of specific kind of activity particularly involving the methods, processes, procedures and techniques relative to the physical education program of the universityimplemented as presented from the mean score of 2.29. Moreover, the head/dean assessed the utilization of specific kind of activity particularly involving the methods, processes, procedures and techniques relative to the physical education program of the university fully implemented as reflected from the mean score of 3.74 but implemented the application of the computer-aided instruction in teaching based on the mean score of 2.49. As a whole, the three groups of respondents - students, teachers 
and principals assessed that the physical education program was implemented as seen from the over-all mean score of $3.14,3.00$ and 3.41 , respectively.

Results of the interview reveal that the teachers are keeping abreast with the latest trends in teaching physical education. The basic strategies can not always be left behind like the use of various type of teaching approaches and specific kind of activity particularly involving the methods, processes, procedures and techniques relative to the physical education program of the university.

On the similar view, Haupt (2010) realigned his concept of h teaching strategies and approaches as elemental in the success of physical education delivery to the students. More likely, Espanol (2009) stressed that the utilization of the different teaching methodologies enhances students' learning motivation and capability as gauged in the students' academic performance.

1.5 Evaluation. Table 5 shows the extent of implementation of the physical education in state universities in terms of evaluation.

Table 5. Status of the Implementation of the Physical Education in State Universities as to Evaluation

\begin{tabular}{|l|l|l|l|l|l|l|}
\hline Evaluation & \multicolumn{2}{l|}{ Students } & \multicolumn{2}{l|}{ Teacher } & \multicolumn{2}{l|}{ Head } \\
\cline { 2 - 7 } & Mean & VI & Mean & VI & Mean & VI \\
\hline $\begin{array}{l}\text { Adopt appropriate assessment strategies to evaluate } \\
\text { the children }\end{array}$ & 3.20 & I & 2.43 & MI & 3.27 & I \\
\hline $\begin{array}{l}\text { Utilize different evaluative measures to rate the } \\
\text { students' growth }\end{array}$ & 3.12 & I & 2.29 & MI & 3.34 & I \\
\hline Use written examinations & 3.40 & I & 3.72 & FI & 3.48 & I \\
\hline Use practical examinations & 3.28 & I & 3.43 & I & 3.66 & FI \\
\hline $\begin{array}{l}\text { Develop skills among their students by assigning a } \\
\text { particular responsibility through searching questions } \\
\text { rather than giving answers }\end{array}$ & 3.04 & I & 3.57 & FI & 3.59 & FI \\
\hline Promote the optimum development of the students & 3.46 & I & 3.71 & FI & 3.51 & FI \\
\hline Over-all Mean Score & $\mathbf{3 . 2 5}$ & I & $\mathbf{3 . 1 9}$ & I & $\mathbf{3 . 4 8}$ & I \\
\hline
\end{tabular}

It was found out that the students assessed the physical education program in the promotion of the optimum development of the students implemented and in developing skills among their students by assigning a particular responsibility through searching questions rather than giving answers as seen from the mean score of 3.46 and 3.04 , respectively.

On the other hand, teachers assessed that the physical education program fully implemented in providing written examinations as indicated from the mean score of 3.72 but moderately implemented the utilization of different evaluative measures to rate the students' growth from the mean score of 2.29. Moreover, the principal assessed the physical education program fully implemented the use of practical examinations based from the mean score 3.66 but implemented the adoption of appropriate assessment strategies to evaluate the children as indicated from the mean score 3.27. As a whole, the three groups of respondents - students, teachers and principals assessed that the physical education program was implemented as seen from the over-all mean score of $3.25,3.19$ and 3.48 , respectively.

Evans (2009) reiterated that the students' performance can be measured through the use of appropriate evaluative materials. Teachers may use different tools such as test, exams, drills, exercises, etc. The students learning and development can be measured during their entire stay in the school that can be manifested in their assessment on the implementation of the physical education in state universities. According to Bencraft (2009) physical health allows students to function even better in classrooms. Research has shown that there is a positive correlation between brain development and exercising. This findings jived with the study of Harris (2009) saying that incorporating theories and concepts into physical education can lead to many meaningful experiences and a way of learning. 


\section{Problem 2. Skills Developed by the Students as Reflected in the Performance Evaluation} evaluation

The following tables illustrate the skills developed by the students as reflected in the performance

2.1 Conceptual Skills. Table 6 depicts the conceptual skills developed by the students as reflected in the performance.

As seen from the table, the students assessed themselves very satisfactory in promoting academic learning based from the mean score 3.91 but satisfactory in acquiring basic knowledge in different theories in sports as indicated from the mean score 3.03. On the other hand, the teachers assessed their students very satisfactory in familiarizing with the different styles/skills in playing sports as seen from the mean score 3.72, but satisfactory in learning the value of taking care of themselves thru proper grooming, healthy eating and regular exercise as indicated from the mean score 3.29. Moreover, the principals assessed their students very satisfactory in inculcating desirable values such as self-discipline, honesty, teamwork, sportsmanship, excellence, etc. and in providing more capabilities and competencies for students to restructure their physiological and mechanical functions as indicated from the mean score of 3.73 and 3.54, respectively.

Table 6. Conceptual Skills Developed by the Students as Reflected in the Performance

\begin{tabular}{|c|c|c|c|c|c|c|}
\hline \multirow[t]{2}{*}{ Conceptual Skills } & \multicolumn{2}{|c|}{ Students } & \multicolumn{2}{|c|}{ Teacher } & \multicolumn{2}{|l|}{ Head } \\
\hline & Mean & VI & Mean & VI & Mean & VI \\
\hline $\begin{array}{l}\text { Learn the value of taking care of themselves thru proper } \\
\text { grooming, healthy eating and regular exercise }\end{array}$ & 3.44 & $\mathrm{~S}$ & 3.29 & $\mathrm{~S}$ & 3.56 & VS \\
\hline Promotes academic learning & 3.91 & VS & 3.71 & VS & 3.56 & VS \\
\hline Allows students to function better in classrooms & 3.39 & $\mathrm{~S}$ & 3.57 & VS & 3.62 & VS \\
\hline $\begin{array}{l}\text { Develop appreciation in the development of physical } \\
\text { education }\end{array}$ & 3.31 & $\mathrm{~S}$ & 3.57 & VS & 3.62 & VS \\
\hline Familiarizes with the different styles/skills in playing & 3.11 & $\mathrm{~S}$ & 3.72 & VS & 3.65 & VS \\
\hline Acquire basic knowledge in different theories in sports & 3.03 & $\mathrm{~S}$ & 3.43 & $\mathrm{~S}$ & 3.56 & VS \\
\hline Develops cooperation, teamwork and sportsmanship skill & 3.36 & $\mathrm{~S}$ & 3.57 & VS & 3.56 & VS \\
\hline $\begin{array}{l}\text { Inculcate desirable values such as self-discipline, honesty, } \\
\text { teamwork, sportsmanship, excellence, etc. }\end{array}$ & 3.36 & $\mathrm{~S}$ & 3.71 & VS & 3.73 & VS \\
\hline $\begin{array}{l}\text { Provide more capabilities and competencies for students to } \\
\text { restructure their physiological and mechanical functions }\end{array}$ & 3.04 & $\mathrm{~S}$ & 3.56 & VS & 3.54 & VS \\
\hline $\begin{array}{l}\text { Enhances students' emotional traits like self-confidence, self- } \\
\text { control, self-reliance, courage and determination }\end{array}$ & 3.21 & $\mathrm{~S}$ & 3.55 & VS & 3.64 & VS \\
\hline $\begin{array}{l}\text { Foster self-discipline, teamwork, and excellence for the } \\
\text { development of a healthy and alert citizenry }\end{array}$ & 3.21 & $\mathrm{~S}$ & 3.57 & VS & 3.62 & VS \\
\hline Over-all Mean Score & 3.31 & $\mathrm{~S}$ & 3.57 & VS & 3.61 & VS \\
\hline
\end{tabular}

As a whole, the three groups of respondents - the students, teachers and the heads/deans have assessed that the students were satisfactory in terms of their performance on cognitive skills as reflected from the mean score of $3.31,3.57 \quad$ and 3.61, as in order.

In an interview with the respondents, they said that their students are performing satisfactory in acquiring basic knowledge in different theories in sports and in understanding with the different styles/skills in playing. Benson (2009) defined conceptual skills pertains to the physical education activities the students develop as to their mental capacities in learning the mechanical principles underlying movements, as they acquire knowledge and understanding of rules and strategies of games and sports, and as they discover ways of improving his movements in gymnastics and dance.

Katz (2008) amplified further that conceptual skill involves the ability to see the enterprise as a 
whole for the simple reason that it includes among others the various functions of the physical education program. As told by Amoore (2009) cognitive skills is nothing more but an involvement of thinking in terms of relative emphasis and priorities; among conflicting objectives and criteria; relative tendencies and probabilities; rough correlations and patterns among elements rather than clear cut cause-and-effect relationship of the physical education program.

2.2 PsychomotorSkills. Table 7 projects the psychomotor skills developed by the students as reflected in the performance.

Table 7. Psychomotor Skills Developed by the Students as Reflected in the Performance

\begin{tabular}{|l|l|l|l|l|l|l|}
\hline Psychomotor Skills & \multicolumn{2}{l|}{ Students } & \multicolumn{2}{l|}{ Teacher } & \multicolumn{2}{l|}{} \\
\cline { 2 - 7 } & Mean & VI & Mean & VI & Mean & VI \\
\hline Physical education develops the students' motor skills & 3.44 & $\mathrm{~S}$ & 3.57 & $\mathrm{~V}$ & 3.46 & $\mathrm{~S}$ \\
\hline Develops body muscles through activities & 3.43 & $\mathrm{~S}$ & 3.43 & $\mathrm{~S}$ & 3.51 & VS \\
\hline Builds self esteem & 3.16 & $\mathrm{~S}$ & 3.57 & $\mathrm{VS}$ & 3.39 & $\mathrm{~S}$ \\
\hline $\begin{array}{l}\text { Encourage students to be active in physical activities like } \\
\text { basketball, volleyball, martial arts, etc. }\end{array}$ & 3.26 & $\mathrm{~S}$ & 3.43 & $\mathrm{~S}$ & 3.64 & VS \\
\hline Promote sports and physical fitness & & & & & \\
\hline $\begin{array}{l}\text { Enhance opportunities for the development of desirable } \\
\text { social traits: friendliness, cooperation, respect for the } \\
\text { rights of others, good sportsmanship, good leadership and } \\
\text { follower ship, and honesty in group competition }\end{array}$ & 3.54 & $\mathrm{VS}$ & 2.29 & $\mathrm{~S}$ & 3.58 & VS \\
\hline Provide selected physical education activities & & & & & \\
\hline Over-all Mean Score & 3.29 & $\mathrm{~S}$ & 3.43 & $\mathrm{~S}$ & 3.56 & VS \\
\hline
\end{tabular}

It can be seen from the table that the students assessed themselves very satisfactory in enhancing opportunities for the development of desirable social traits: friendliness, cooperation, respect for the rights of others, good sportsmanship, good leadership and follower ship, and Honesty in group competition as indicated from the mean score of 3.54, but satisfactory in building self-esteem indicated from the mean score 3.16. On the other hand, the teachers assessed their students very satisfactory in promoting sports and physical fitness as seen from the mean score 3.92 but satisfactory in enhancing opportunities for the development of desirable social traits: friendliness, cooperation, respect for the rights of others, good sportsmanship, good leadership and follower ship, and honesty in group competition from the mean score 2.29. Moreover, the principals assessed their students very satisfactory in encouraging students to be active in physical activities like basketball, volleyball, martial arts, etc. as seen from the mean score 3.64, but satisfactory in building selfesteem as indicated from the mean score 3.39. As a whole, the principals have assessed that the students were very satisfactory in their performance as to psychomotor skills as seen from the mean score of 3.52 while assessed by the students themselves and the teachers satisfactory based on the mean score of 3.36 and 3.39 , respectively.

The role of the physical education in the development of psychomotor skills of students is very important. Myers (2009) disclosed that muscular strength increases agility, speed and flexibility of the students are improved with the appropriate sports activity. However the essence of maintaining physical fitness may not be achieved without adequate sleep, good nutrition and systemic exercise and the aftermath of which is development of muscular strength.

Nydegger (2008) conceived the essential element of the delivery of quality physical education program is the enhancement of students' psychomotor skills. A similar disclosure was propounded by Murray (2009) that linked with the components of the physical fitness along the enhancement of muscular strength as fully developed by the physical education delivery mechanisms of the selected state universities in the region. 
2.3 Technical Skills. Table 8 displays the technical skills developed by the students as reflected in the performance.

Table 8. Technical Skills Developed by the Students as Reflected in the Performance

\begin{tabular}{|c|c|c|c|c|c|c|}
\hline \multirow[t]{2}{*}{ Technical Skills } & \multicolumn{2}{|c|}{ Students } & \multicolumn{2}{|c|}{ Teacher } & \multicolumn{2}{|l|}{ Head } \\
\hline & Mean & VI & Mean & VI & Mean & VI \\
\hline - $\quad$ Acquire the value of regular exercise & 3.09 & $\mathrm{~S}$ & 3.14 & $\mathrm{~S}$ & 3.52 & VS \\
\hline $\begin{array}{l}\text { - Acquire skills in playing different kinds of } \\
\text { sports }\end{array}$ & 3.41 & $\mathrm{~S}$ & 3.57 & $\mathrm{~S}$ & 3.57 & VS \\
\hline $\begin{array}{l}\text { - Attain competencies in playing recreational } \\
\text { games }\end{array}$ & 3.13 & $\mathrm{~S}$ & 3.00 & $\mathrm{~S}$ & 3.57 & VS \\
\hline - Teach students the value of regular exercise & 2.86 & $\mathrm{~S}$ & 3.73 & VS & 3.64 & VS \\
\hline Promotes a physically active lifestyle & 3.25 & $\mathrm{~S}$ & 3.71 & VS & 3.55 & VS \\
\hline $\begin{array}{l}\text { Attain optimal level of activities conducive to good } \\
\text { health }\end{array}$ & 3.39 & $\mathrm{~S}$ & 3.57 & VS & 3.61 & VS \\
\hline $\begin{array}{l}\text { Enhance students' growth and development through body } \\
\text { movement }\end{array}$ & 3.12 & S & 3.57 & VS & 3.52 & VS \\
\hline Undertake regular sports activities & 2.78 & $\mathrm{~S}$ & 3.16 & $\mathrm{~S}$ & 3.52 & VS \\
\hline $\begin{array}{l}\text { Make physical education an internal part of the } \\
\text { educational program of the state universities }\end{array}$ & 3.25 & $\mathrm{~S}$ & 3.14 & $\mathrm{~S}$ & 3.47 & $\mathrm{~S}$ \\
\hline $\begin{array}{l}\text { Transmit values and standards that are consistent with the } \\
\text { needs and ideals of society }\end{array}$ & 3.32 & $\mathrm{~S}$ & 3.13 & $\mathrm{~S}$ & 3.62 & $\mathrm{VS}$ \\
\hline Over-all Mean Score & 3.16 & $\mathrm{~S}$ & 3.37 & $\mathrm{~S}$ & 3.56 & VS \\
\hline
\end{tabular}

Based on the students self-rating, it was found out that the students are very satisfactory in acquiring skills in playing different kinds of sports as indicated from the mean score of 3.41 but satisfactory in undertaking regular sports activities based on the mean score of 2.78. On the other hand, teachers assessed the students very satisfactory in teaching their students acquire value of regular exercise as seen from the mean score 3.73, but satisfactory in attaining competencies in playing recreational games as indicated from the mean score 3.13. Furthermore, the head assessed the students very satisfactory in transmitting values and standards that are consistent with the needs and ideals of society indicated from the mean score 3.62, but satisfactory in making physical education an internal part of the educational program of the state universities as seen from the mean score 3.47. As a whole, the head have assessed that the students were very satisfactory in their performance as to psychomotor skills as seen from the mean score of 3.56 while assessed by the students themselves and the teachers satisfactory based on the mean score of $3.16 \quad$ and 3.37 , respectively.

The state universities are doing their best to enhance the students' technical skills. Toward this end, state universities have exerted their efforts by making physical education management delivery mechanisms accessible and thus producing healthy fit citizens who are physically fit in relating to their cardiovascular health, strength and endurance, psychological well-being, self image and social interaction with their surroundings in the region on the local and global spheres.

As spelled out in article XIV, section 19 subsections 1 and 2 of the 1987 Philippine Constitution, "The State shall promote physical education and encourage sports programs, league competitions, and amateur sports, including training for international competitions, to foster self-discipline, teamwork, and excellence for the development of a healthy and alert citizenry" and "all education institutions shall undertake regular sports activities throughout the country in cooperation with athletic clubs and other sectors" respectively.

\section{Problem 3. Significant Relationship between the Implementation of the Physical Education in State}


Universities and the Skills developed by the students

Table 9 illustrates the significant relationship between the implementation of the physical education in state universities and the skills developed by the students.

There is a high correlation between the implementation of the physical education in state universities and the skills developed by the students as indicated from Pearson's $\mathbf{r}$ of 0.802 . Furthermore, since the computed $\mathbf{t}$-value of 1.713 is greater than the tabular $\mathbf{t}$-value of 1.645 using 0.05 level of significance, the hypothesis was rejected and concludes that there is significant relationship between the implementation of the physical education in state universities and the skills developed by the students.

Table 9. Relationship between the Implementation of the Physical Education and the Skills developed by the Students

\begin{tabular}{|l|l|l|l|l|l|l|}
\hline \multirow{2}{*}{$\begin{array}{l}\text { Variable } \\
\text { Pearson's }\end{array}$} & Correlation & \multicolumn{2}{|c|}{ t } & Decision & Remarks \\
\cline { 3 - 6 } & $\mathbf{R}$ & Comp & Tab & & \\
\hline $\begin{array}{l}\text { Implementation of } \\
\text { the Physical } \\
\begin{array}{l}\text { Education in State } \\
\text { Universities }\end{array}\end{array}$ & 0.802 & $\begin{array}{l}\text { High } \\
\text { Correlation }\end{array}$ & 1.713 & 1.645 & Reject & Significant \\
\hline $\begin{array}{l}\text { Skills developed by } \\
\text { the students }\end{array}$ & & & & & \\
\hline
\end{tabular}

Data shows that the students' skills developed during their entire stay in the school are manifested in their assessment on the implementation of the physical education in state universities. According to Bencraft (2009) physical health allows students to function even better in classrooms. A good cardiovascular system developed from regular exercise promotes excellent blood and oxygen circulation. This means more nutrients circulate through out the body which includes the brain. This circulation produces longer attention span during classes allowing longer concentration and absorption.

Research has shown that there is a positive correlation between brain development and exercising. This findings jived with the study of Harris (2009) saying that incorporating theories and concepts into physical education can lead to many meaningful experiences and a way of learning.

In Brazil, the physical education curriculum is designed to allow school pupils a full range of modern opportunities, dozens of sports and hundreds of carefully reviewed drills and exercises, including exposure to education with the use of pedometer, GPS, and heart rate monitors, as well as state-of-the-art exercise machines in the high school level. Some martial arts classes, like wrestling in the United States, and Pencak Silat in France, Indonesia, and Malaysia, are taught to teach children self-defense and to feel good about themselves.

It was confirmed by Station (2009) that the physical education curriculum is designed to allow students to experience at least a minimum exposure to the following categories of activities: aquatics, conditioning activities, gymnastics, individual/dual sports, team sports, rhythms, and dance. Students are encouraged to continue to explore those activities in which they have a primary interest by effectively managing their community resources. On the other hand, in other countries like Thailand, a planned sequence of learning experiences is designed to support a progression of student development. This allows kids through 6th grade to be introduced to sports, fitness, and teamwork in order to be better prepared for the next year level.

Problem 4. Problems Encountered in the Implementation of the Physical Education Program in State 


\section{Universities}

The data below presents the problems encountered by the respondents in the implementation of the physical education program in state universities.

Problems

There is a problem on the physical resources of the schools like the swimming pool and other resources like gymnasium.

The findings of the foregoing studies suggested a technique of dealing with a problematic situation germane to the solution of similar research undertaking relative to the physical resources as delivery mechanisms of the physical education program by the selected state universities in CALABARZON in the said region.

Human Resources. With regards to the human resources, it was found out that there are still some teachers who are not yet pursuing their graduate degree programs for several reasons like financial, lack of time, lack of motivation, family problems, etc. Kahana (2009) in her position paper pointed out the much needed qualified human resources for effective delivery of physical education program in all state universities.

The above investigations provided possibilities for the present researcher to explore solutions to her problem areas investigated along human resources as delivery mechanisms deployed in the physical education programs of the selected state universities in CALABARZON.

Teaching within the Area of Specialization. Technical skill must be developed comprehensively among students through the use of the tools designed for effective physical education program in sate universities in CALABARZON. This is a problem since there are some faculty members are teaching who are not technically-equipped with the subject they are handling. The teachers' area of specialization is not met.

With the findings revealed by the foregoing researchers, these helped the present researcher to attack the problem areas investigated along the level of technical skill deployed by the selected state universities in the delivery of their physical education programs in the said region.

McClelland (2008) realigned the human management skill with technical aspect to effectively deliver the physical education program through proper motivation of people included in the said program.

\section{Problem 5. Action Plan Developed to Enhance the Implementation of the Physical Education Program in State Universities}

Table 5 presents the program developed by the researcher to enhance the implementation of the physical education program in state universities.

Table 10. Action Plan Developed to Enhance the Implementation of the Physical Education Program in State Universities

\begin{tabular}{|l|l|l|l|l|l|}
\hline Key Areas & Objectives & Strategies & Persons Involved & $\begin{array}{l}\text { Time } \\
\text { Frame }\end{array}$ & Budget \\
\hline Physical Resource & $\begin{array}{l}\text { No hwimming Pool } \\
\text { swimming pool } \\
\text { for the school }\end{array}$ & $\begin{array}{l}\text { Encourage schools } \\
\text { administrators to } \\
\text { construct a swimming } \\
\text { pool }\end{array}$ & Director & $\begin{array}{l}\text { First week } \\
\text { of May }\end{array}$ & $\begin{array}{l}\text { P2 } \\
\text { Million } \\
\text { Request the local }\end{array}$ \\
\hline
\end{tabular}




\begin{tabular}{|c|c|c|c|c|c|}
\hline & $\begin{array}{l}\text { To develop } \\
\text { students } \\
\text { swimming skills }\end{array}$ & $\begin{array}{l}\text { government and the } \\
\text { Department of } \\
\text { Education to assist in } \\
\text { the construction of the } \\
\text { schools' swimming } \\
\text { pool }\end{array}$ & & & \\
\hline \multicolumn{6}{|l|}{ Human Resources } \\
\hline $\begin{array}{l}\text { Meet the required } \\
\text { area of specialization } \\
\text { of the teachers and } \\
\text { heads of the physical } \\
\text { education department }\end{array}$ & $\begin{array}{l}\text { Encourage } \\
\text { department and } \\
\text { teachers to enroll } \\
\text { in the graduate } \\
\text { program }\end{array}$ & $\begin{array}{l}\text { Hire teachers who are } \\
\text { qualified to teach } \\
\text { physical education } \\
\text { subjects } \\
\text { Require departments to } \\
\text { upgrade their } \\
\text { educational } \\
\text { qualifications by } \\
\text { enrolling n the graduate } \\
\text { program }\end{array}$ & $\begin{array}{l}\text { Director } \\
\text { Department Head } \\
\text { Teachers }\end{array}$ & $\begin{array}{l}\text { First week } \\
\text { of May }\end{array}$ & $\begin{array}{l}\mathrm{P} 100,00 \\
0\end{array}$ \\
\hline \multicolumn{6}{|c|}{ Instructional Materials } \\
\hline $\begin{array}{l}\text { Uses modern tools in } \\
\text { teaching like } \\
\text { computers, } \\
\text { powerpoint } \\
\text { presentation, etc. }\end{array}$ & $\begin{array}{l}\text { To improve the } \\
\text { instructional } \\
\text { materials used by } \\
\text { teachers in } \\
\text { Physical } \\
\text { Education } \\
\\
\text { To upgrade the } \\
\text { instructional } \\
\text { materials used by } \\
\text { teachers with } \\
\text { multimedia } \\
\text { integration }\end{array}$ & $\begin{array}{l}\text { Canvass different } \\
\text { instructional materials } \\
\text { used in teaching } \\
\text { Physical Education } \\
\text { particularly that } \\
\text { integrates the use of } \\
\text { multimedia } \\
\text { Conduct a faculty } \\
\text { meeting to reiterate the } \\
\text { use of different kinds } \\
\text { of instructional } \\
\text { activities that promote } \\
\text { student achievement } \\
\text { with the use of } \\
\text { multimedia } \\
\text { technologies } \\
\text { Purchase additional } \\
\text { instructional materials } \\
\text { that utilize multimedia } \\
\text { such as PowerPoint, } \\
\text { computers, cassette } \\
\text { tapes, TV, etc. }\end{array}$ & $\begin{array}{l}\text { Director } \\
\text { Department Head } \\
\text { Teachers }\end{array}$ & $\begin{array}{l}\text { First week } \\
\text { of May }\end{array}$ & $\begin{array}{l}\text { P2Milli } \\
\text { on }\end{array}$ \\
\hline
\end{tabular}




\begin{tabular}{|c|c|c|c|c|c|}
\hline & $\begin{array}{l}\text { To utilize } \\
\text { different kinds of } \\
\text { instructional } \\
\text { activities that } \\
\text { promote student } \\
\text { performance using } \\
\text { multimedia } \\
\text { technologies }\end{array}$ & & & & \\
\hline \multicolumn{6}{|l|}{ Strategies } \\
\hline \multirow[t]{2}{*}{$\begin{array}{l}\text { Apply computer- } \\
\text { aided instruction in } \\
\text { teaching }\end{array}$} & $\begin{array}{l}\text { To encourage } \\
\text { teachers to } \\
\text { develop their own } \\
\text { teaching material } \\
\text { that capitalizes on } \\
\text { the use of } \\
\text { multimedia }\end{array}$ & 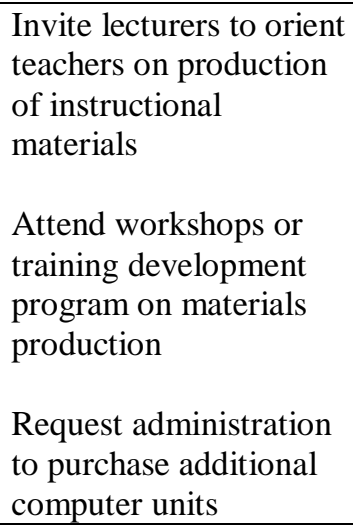 & $\begin{array}{l}\text { Director Department } \\
\text { Head } \\
\text { Teachers }\end{array}$ & $\begin{array}{l}\text { On a regular } \\
\text { basis }\end{array}$ & $\begin{array}{l}\mathrm{P} 750,00 \\
0\end{array}$ \\
\hline & $\begin{array}{l}\text { To enhance } \\
\text { teachers' teaching } \\
\text { methodologies } \\
\text { and approaches }\end{array}$ & $\begin{array}{l}\text { Conduct faculty } \\
\text { development seminars } \\
\text { on teaching strategies } \\
\text { and methodologies } \\
\text { Invite lecturers to } \\
\text { familiarize teachers in } \\
\text { the latest trends in } \\
\text { teaching strategies } \\
\text { using different } \\
\text { multimedia in physical } \\
\text { education }\end{array}$ & $\begin{array}{l}\text { Principal } \\
\text { Department Head } \\
\text { Teachers }\end{array}$ & $\begin{array}{l}\text { Every first } \\
\text { week of the } \\
\text { Year }\end{array}$ & $\begin{array}{l}\mathrm{P} 100,00 \\
0\end{array}$ \\
\hline \multicolumn{6}{|l|}{ Evaluation } \\
\hline $\begin{array}{l}\text { Utilize different } \\
\text { evaluative measures } \\
\text { to rate the students' } \\
\text { growth }\end{array}$ & $\begin{array}{l}\text { To encourage } \\
\text { administrators to } \\
\text { help teachers } \\
\text { improve } \\
\text { evaluative } \\
\text { measures }\end{array}$ & $\begin{array}{l}\text { Conduct faculty } \\
\text { development seminars } \\
\text { to familiarize teachers } \\
\text { in the latest trends in } \\
\text { students' measurement }\end{array}$ & $\begin{array}{l}\text { Director } \\
\text { Department Head } \\
\text { Teachers }\end{array}$ & $\begin{array}{l}\text { Every first } \\
\text { week of } \\
\text { June }\end{array}$ & $\begin{array}{l}\mathrm{P} 150,00 \\
0\end{array}$ \\
\hline
\end{tabular}

\section{CONCLUSIONS AND ECOMMENDATIONS}

This chapter presents the summary of findings from the gathered data and analyzed data, the conclusions drawn from the findings and recommendations offered by the researcher in the light of the findings and conclusions.

From the data yielded from the instruments, the researcher summarized the following data.

\section{Extent of Implementation of the Physical Education in State Universities in CALABARZON}



universities.

Data below summarizes the status of the implementation of the physical education in state

1.1. Physical Resources. The three groups of respondents - students, teachers and principals assessed that the physical education program was implemented as seen from the over-all mean score of 2.82 , 3.24 and 3.42 , as in order.

1.2. Human Resources. Data reveals that the head/dean assessed the physical education program fully implemented as seen from the over-all mean score of 3.65 but the students and teachers assessed it implemented as reflected from the over-all mean score of 3.39 and 3.43 , respectively.

1.3 Instructional Materials. Findings show that the head/dean have assessed that the physical education program was fully implemented as seen from the mean score of 3.53 while the students and teachers assessed it implemented as reflected from the mean score of 3.30 and 3.07, respectively.

1.4 Strategies. It was found out that the three groups of respondents - students, teachers and head/dean assessed that the physical education program was implemented as seen from the over-all mean score of 3.14, 3.00 and 3.41, respectively.

1.5 Evaluation. The three groups of respondents - students, teachers and head/dean assessed that the physical education program was implemented as seen from the over-all mean score of 3.25, 3.19 and 3.48, respectively.

\section{Skills Developed by the Students as Reflected in the Performance}

Data below summarizes the skills developed by the students as reflected in the performance.

\section{Skills Developed by the Students as Reflected in the Performance}

Data below summarizes the skills developed by the students as reflected in the performance.

2.1 Conceptual Skills. Findings show that the three groups of respondents - the students, teachers and the head/dean have assessed that the students were satisfactory in terms of their performance on cognitive skills as reflected from the mean score of 3.31, 3.57 and 3.61, as in order.

2.2 PsychomotorSkills. It was found out that the head/dean have assessed that the students were very satisfactory in their performance as to psychomotor skills as seen from the mean score of 3.52 while assessed by the students themselves and the teachers satisfactory based on the mean score of 3.36 and 3.39 , respectively.

2.3 Technical Skills. The head/dean have assessed that the students were very satisfactory in their performance as to psychomotor skills as seen from the mean score of 3.56 while assessed by the students themselves and the teachers satisfactory based on the mean score of 3.16 and 3.37, respectively.

3. Significant Relationship between the Implementation of the Physical Education in State Universities and the Skills developed by the students

Since the computed $\mathbf{t}$-value of 1.713 is greater than the tabular $\mathbf{t}$-value of 1.645 using 0.05 level of significance, the hypothesis was rejected and concludes that there is significant relationship between the implementation of the physical education in state universities and the skills developed by the students.

4. Problems Encountered in the Implementation of the Physical Education Program in State Universities

The problems encountered by the respondents were lack of swimming pool and the use of the teaching strategies of teachers designed for effective physical education program in sate universities in CALABARZON.

5. Program Developed to Enhance the Implementation of the Physical Education Program in State Universities

Based on the findings of the study, the researcher was able to develop a program to enhance the implementation of the physical education program in state universities.

\section{Conclusions}


Based on the findings of the study, the following conclusions are drawn:

1. The Physical Education in State Universities in CALABARZON is not fully implemented in terms of physical resources, human resources, instructional materials, strategies and evaluation.

2. The head/dean have assessed that the students' performance in physical education is very satisfactory but assessed by the teachers and students themselves satisfactory in terms of the conceptual, psychomotor and technical skills.

3. Significant relationship exists between the implementation of the physical education in state universities and the skills developed by the students.

4. The problems encountered by the respondents were lack of swimming pool and the use of the teaching strategies of teachers designed for effective physical education program in sate universities in CALABARZON.

5. The researcher developed an action plan to enhance the implementation of the physical education program in state universities.

\section{Recommendations}

Based on the findings and conclusions of the study, the following recommendations were forwarded:

1. Assess the Physical Education program in the state universities in CALABARZON to address the specific concerns in areas in the physical resources, human resources, instructional materials, strategies and evaluation which were not fully implemented.

2. Teachers need to develop strategies to improve the students' performance in physical education in terms of the conceptual, psychomotor and technical skills.

3. Develop strategies to solve the problems encountered by the respondents pertaining to lack of swimming pool and the use of the teaching strategies of teachers designed for effective physical education program in sate universities in CALABARZON.

4. Utilize the action plan developed by the researcher to enhance the implementation of the physical education program in state universities in CALABARZON.

\section{BIBLIOGRAPHY}

\section{A. BOOKS}

Amoore, John (2008) Managerial Technical Skills. New Jersey: Lawrence Erlbawn Associates.

Aray, L.B. (2008) Physical Resources for Health Education Program. Philadelphia: J.B. Lippincott Co.

Arul, M.J. (2012) Managerial Skills. Columbia: Institute of Rural Management

Bell, Gilbert H (2008) Physical Resource Delivery. California: Large Medical Publications

Chaffee, Edwin (2008) Health Service Delivery. Boston: Little, Brown and Co.

Chapman, Charles (2008). Human Resources, The Foundation of Effective Health Service Delivery. Philadelphia: Scientific American

Haupt, Richard (2009). Human Resource Aspect of Health Service. Los Altos: Annual Review of Physiology

Huxley, Alexander (2009). Deployment of Health Service Delivery thru Human Resources. Baltimore: Williams and Wilkins, Co.

Juacalla, Ben (2013) Fiscal Management of Physical Education Service Delivery of State Universities in CALABARZON. A Dissertation, Philippine College of Health and Sciences Graduate School, Manila.

Katz, Bernard (2008). Managerial Skill in Technology. New York: Mc Graw Hill

Langen, James (2008). Technological and Human Skills in Industrial Management. Atlanta: Southern Regional Education Board.

Murray, James (2009). Systemic Circulation. New York: Journal for Philosophy

Myers, Daniel (2009). Physical Fitness. New England: Journal of Medicine 
Nydegger, Charles N (2009). Middle Age Syndrome U.S.A.: Journal of Aging and Human Development Rebuck, James (2008). Lymphocyte and Lymphatic Tissue affecting Physical Fitness. New York: Paul B. Hoeber

Reich, Charles (2008). The Cellular Elements of the Vlood. New York: CIBA Clinical Symposia

Schwartz, Wilson (2008). Peripheral Circulation. New York: Annual Review of Physiology

Philippine Regional Profiles (2009) Quezon City: KASIMBAYAN, Inc.

\section{B. Published and Unpublished Materials}

Amundsen, Victor K. (2009) "Physical Resources of Country Schools for seniors". California: An Institutional Research

Burke, Roger (2009) "Physical Resources for Human Development Program" Chicago: A Feasibility Study

Kahana, Carol E (2009) "Physical Resources for Physical Fitness program for Patients in the Rehabilitation Center." Boston: A Position Paper

Mormor, Michael (2008) "Technical Skill in the Physical Education Program.” New Jersey: An Institutional Research for Physical Education Journal

McClelland, Peter (2008) “ The Technicality of Physical Education Program. Florida: An Institutional Study

Mc Daniels, Daniel (2008) Technical Perspective of Physical Education Program. Pittsburg: An Institutional Study for Physical Education Program Journal.

\section{Webliography}

Wikipedia, 2011www. Sibs.com.ph "Philippines EIA". Emb.gov.ph. Retrieved 2012-10-29

“Los Baños, Laguna-Science and Nature City” Losbanos.gov.ph. Retrieved 2012-10-29

"Information for Prospective Students | University of the Philippines Los Baños. Old.uplb.edu.ph. Retrieved 2012-10-29

\section{Journals}

Educator's Journal, Vol. 23, no. 11, summer, 2004

Educator's Journal, Vol.24, no.6, November 2004

Educator's Journal, Vol. 35, no. 85, November 2013

Population Counts-CALABARZON, National Statistics Office, Retrieved March 9, 2013

Star: The mark of Sakay: The vilified hero of our war with America, Retrieved March 9, 2013

GRDP by region, National Statistical Coordination Board, Retrieved March 10, 2013

“Los Baños”. Laguna Travel Guide. 2000-09-17. Retrieved 2012-10-29

The 2010 Census of Population and Housing Reveals the Philippine Population at 92.34 Million, National Statistics Office, retrieved March 10, 2013

Quickstat on Region IV-A (CALABARZON)- February 2013, National statistics Office, Retrieved March 10, 2013

National Commission for Culture and Arts: Tagalog, National Commission for Culture and Arts

A review of the Agriculture Sector in CALABARZON National Statistics Office, Retrieved March 11, 2013 